ISSN 0258-7122

Bangladesh J. Agril. Res. 34(1) : 91-96, March 2009

\title{
GENETIC VARIATION AND TRAIT RELATIONSHIP IN THE EXOTIC AND LOCAL EGGPLANT GERMPLASM
}

\author{
M. S. ISLAM ${ }^{1}$ AND M. S. UDDIN ${ }^{2}$
}

\begin{abstract}
Sixteen genotypes of local and exotic germplasms were studied to estimate variability, hcritability, genetic advance, and correlation coefficients. High genotypic and phenotypic coefficients of variation were obtained for number of fruits/plant, individual fruit weight, and yield per plant. Heritability and genetic advance were also high for these traits indicating the possibility of selection to improve these characters. Yield of fruits showed highly significant and positive association with number of fruits per plant and individual fruit weight, which indicate the importance of these characters during selection for high yielding genotypes in eggplant. Among the genotypes, Islampuri produced the highest fruit yield (58.8 t/ha) followed by Tall begun (52.8 t/ha) and EG 120 (49.6 t/ha). Incidence of borer infestation ranged from 3.0 to $20.6 \%$. The lowest borer infestation was found in EG 120 (3.0\%), while it was the highest in EG 192 (20.6\%)
\end{abstract}

Kew Words: Genetic variation, trait relationship, exotic and local germplasm, eggplant.

\section{Introduction}

Brinjal (Solanum melongena) is one of the important vegetable crops grown in all parts of Bangladesh (Rashid, 1995). It has a positive role in both summer and winter to fulfill the market demand of vegetables of Bangladesh. Yield potentiality of the varieties cultivated in Bangladesh is less and choice of brinjal size, shape, and skin colour varies in different locations. Improvement in fruit yield, colour, and insect resistances will certainly enhance the production and consumption of the crop. Genetic variability of brinjal has been studied by various workers in India (Misra, 1961; Thakur et al., 1968) and also in Bangladesh (Basar, 1999; Chowdhury, 2005). For improvement programme, the information about variability is a prerequisite. The phenotypic variability among a collection of genetic stocks gives an indication of potential genotypic variability, however, the quantitative characters are greatly influenced by the environment. Therefore, information of the extent of variability available in some important economic traits and their heritability will be helpful to the breeders to formulate sound breeding programmes. Hence, the present study was undertaken

${ }^{1}$ Senior Scientific Officer, HRC, BARI, ${ }^{2}$ Scientific Officer, Plant Breeding Division, BART, Gazipur, Bangladesh. 
to evaluate yield performance, to estimate the extent of variability, heritability and expected genetic advance of sixteen exotic and local eggplant germplasm.

\section{Materials and Method}

The present study was conducted at Agriculture Research Station, Pahartali, Chittagong with 16 diverse genotypes of eggplant during November 1999 to March 2000. Twelve genotypes of eggplant were collected from AVRDC, Taiwan and remaining four were from local source. The experiment was set up in a randomized complete block design with three replications. Seeds were sown on 17 November in the nursery bed and one month old seedlings were transplanted in the main field. Manures and fertilizers were applied as per recommendation given by Rashid (1995). Unit plot size was $1.5 \mathrm{~m}$ x $5.0 \mathrm{~m}$ where plants were spaced at $75 \mathrm{~cm} \times 50 \mathrm{~cm}$. Irrigation and other cultural operations were done as and when necessary. Observations were recorded from 10 randomly selected plants of each plot for plant height, days to flowering, number of fruits per plant, individual fruit weight, yield, fruit length, and breadth and percent borer infested fruit. The analysis of variance and simple correlation and coefficient were worked out according to Panse and Sukhatme (1967). Phenotypic and genotypic coefficient of variability, heritability, and expected genetic advance were determined according to Burton and De Vane (1953).

\section{Results and Discussion}

The mean performances of the genotypes for yield and yield attributes are given in Table 1 . The extent of variability for the characters in different genotypes measured in terms of range and coefficient of variation, genotypic coefficient of variation (GCV), phenotypic coefficient of variation (PCV) along with the amount of heritability $\left(\mathrm{h}^{2}\right)$ expected genetic advance as percent at mean are given in Table 2.

The genotypes differed significantly for all the characters studied except plant height. Days to first flowering were ranged from 67 days to 70 days. Ahmed et al. (1988) also found that 59 to 94 days were required for first flower depending upon the variety. The line EG195 and BJ001 took 67 days to first flower, while it was 78 days for EG219. Significant variation was found in number of fruits production per plant. The line EG 120 produced the highest number of fruits per plant (46.6), which was identical to Uttara (46.0). The lowest number of fruits was produced by the genotype EG195 (6.6). Fruits obtained from the genotype S56B were found smaller in respect of individual fruit weight (25.3 g), while Tall begun and Islampuri had the fruits with higher individual fruit weight (157 g and $128 \mathrm{~g}$, respectively). Similarly highest per hectare yield was obtained from the variety Islampuri (58.8 $\mathrm{t} / \mathrm{ha}$ ) followed by Tall begun (52.8 t/ha) and EG 120 (49.6 t/ha). The genotype EG192 showed the lowest yielding potentiality (85 t/ha). Basar (1999) also observed significant variation for number of flowers per inflorescence, number of fruits per plant, fruit 
length, fruit breadth, and fruit weight among 30 brinjal genotypes. Fruit infestation by borer ranged from 3\% to 20\%. Fruits of EG 120 were less infested by borer (3\%), while $20 \%$ of the fruit of EG192 was infested.

Table 1. Yield and yield attributes of 16 eggplant germplasm.

\begin{tabular}{|c|c|c|c|c|c|c|c|}
\hline Lines & $\begin{array}{l}\text { Days to } \\
\text { first } \\
\text { flowering }\end{array}$ & $\begin{array}{l}\text { Plant } \\
\text { height } \\
(\mathrm{cm})\end{array}$ & $\begin{array}{c}\text { No. of } \\
\text { fruits/plant }\end{array}$ & $\begin{array}{l}\text { Individual } \\
\text { fruit wt(g) }\end{array}$ & $\begin{array}{l}\text { Yield/ } \\
\text { pland } \\
(\mathrm{kg})\end{array}$ & $\begin{array}{l}\text { Yield } \\
\text { (t/ha) }\end{array}$ & $\begin{array}{c}\text { \% shoot } \\
\text { and fruit } \\
\text { borer } \\
\text { infestation }\end{array}$ \\
\hline S3 & 686ab & 78.6 & 9.7ab & $84.3 g$ & $0.81 d$ & $21.7 d$ & 8.8abc \\
\hline S474 & 75.3ef & 73.2 & 7.0a & 64.6ef & $0.45 a b c$ & 11.98abc & 13.6bcd \\
\hline SS6B & 740de & 7.53 & $23.6 \mathrm{e}$ & 25.3a & $0.58 c$ & $15.5 c$ & $5.6 a b$ \\
\hline S69 & 69.6ab & 77.0 & 13.3bc & 30.3ab & $0.39 a$ & $10.4 \mathrm{a}$ & 5.8abc \\
\hline S90 & 68.6ab & 75.3 & $16.0 \mathrm{~cd}$ & 35.3bc & $0.56 \mathrm{bc}$ & $14.9 \mathrm{bc}$ & 7.6abc \\
\hline EG120 & 69.3abc & 74.3 & $46.6 g$ & $40.0 c$ & $1.86 f g$ & 49.6fg & $3.0 \mathrm{a}$ \\
\hline EG192 & 72.0b-e & 72.0 & 5.3a & $60.3 e$ & $0.32 \mathrm{a}$ & $8.5 a$ & $20.6 d$ \\
\hline EG193 & 70.0a-d & 74.3 & $12.0 \mathrm{bc}$ & $34.6 b c$ & $0.41 \mathrm{ab}$ & 10.9ab & 13.3a-d \\
\hline EG195 & $67.0 \mathrm{a}$ & 74.2 & 6.6a & $67.3 f$ & 0.44abc & 11.8abc & $15.0 \mathrm{~cd}$ \\
\hline EG203 & 70.6a-d & 75.4 & $12.0 \mathrm{bc}$ & $67.6 \mathrm{f}$ & $0.81 d$ & 21.1d & 7.7abc \\
\hline EG219 & $78.6 \mathrm{f}$ & 74.5 & 9.3ab & $51.0 \mathrm{~d}$ & $0.47 \mathrm{abc}$ & 12.3abc & 11.1abc \\
\hline EG190 & 72.0b-e & 76.8 & $27.6 \mathrm{e}$ & $34.0 \mathrm{bc}$ & $0.93 d$ & $24.3 d$ & 8.9abc \\
\hline Uttara & 73.0cde & 76.4 & $46.0 \mathrm{~g}$ & $38.3 c$ & $1.76 \mathrm{f}$ & $45.7 f$ & 5.8abc \\
\hline $\begin{array}{l}\text { Tall } \\
\text { Begum }\end{array}$ & 72.0b-e & 75.8 & $13.0 \mathrm{bc}$ & $157.6 \mathrm{i}$ & $2.03 \mathrm{~g}$ & $52.8 \mathrm{~g}$ & 7.8abc \\
\hline BJ001 & $67.0 \mathrm{a}$ & 77.8 & 33.0f & $37.6 c$ & $1.23 \mathrm{e}$ & $32.1 \mathrm{e}$ & 4.2ab \\
\hline Islampuri & 68.0ab & 75.4 & $17.6 \mathrm{~d}$ & 128.3h & $2.26 \mathrm{~h}$ & $58.8 \mathrm{~h}$ & 8.5abc \\
\hline CV (\%) & 3.2 & 4.5 & 13.2 & 5.9 & 10.2 & 9.5 & 50.9 \\
\hline
\end{tabular}

Means followed by the same letter (s) in a column are not significantly different at $5 \%$ level.

The highest GCV (70.7) associated with higher heritability (96\%) resulting in a highest amount of genetic advance (144) as percent of mean was observed for number of fruits per plant. The fruit yield per plant also exhibited high GCV (69\%) and heritability (98.5\%) with genetic advance of 141 as percent of mean. Ushakumary et al. (1991) evaluated 54 eggplant genotypes and observed that phenotypic coefficients of variation were higher than genotypic coefficients of variation for all the characters and all characters showed high heritability and genetic advance. Robinson et al. (1959) has arbitrarily categorized the estimates of heritability as low (5-10\%), medium (10-30\%), and high (above $30 \%$ ). Following the classification, the heritability estimates obtained for all the characters except plant height and \% borer infestation were quite high in the present investigation (Table 2). Such high heritability estimates have been found to be helpful in making selection of superior genotypes on the basis of phenotypic performance for quantitative characters. However, the heritability estimates along with genetic gain is more useful than the heritability values alone in predicting the resultant effect for selecting the best individuals. In present investigation, number of fruits per plant, individual fruit weight, and yield per 
Table 2. Variability and heritability estimates in eggplant genotypes

\begin{tabular}{|c|c|c|c|c|c|c|c|c|c|}
\hline Traits & Range & Mean & $\begin{array}{l}\text { Genotypic } \\
\text { variance }\end{array}$ & $\begin{array}{l}\text { Phenotypic } \\
\text { variance }\end{array}$ & GCV & PCV & $\begin{array}{c}\text { Heritability } \\
\text { (\%) }\end{array}$ & $\begin{array}{c}\text { Genetic } \\
\text { advance } \\
\text { (GA) }\end{array}$ & $\begin{array}{l}\text { GA in \% } \\
\text { of mean }\end{array}$ \\
\hline Days to first flowering & $67.0-78.8$ & 70.6 & 8.6 & 13.7 & 4.18 & 5.2 & 62.7 & 5.5 & 7.8 \\
\hline Plant height & 72.0-78.6 & 75.4 & 1.025 & 12.72 & 1.33 & 4.7 & 8.01 & 0.95 & 1.2 \\
\hline Number of fruits/pant & $7.0-46.0$ & 18.6 & 173.0 & 179.0 & 70.7 & 72.0 & 96.0 & 26.9 & 144.0 \\
\hline Individual fruit fruits wt (g) & 25.3-157.6 & 59.7 & 1355 & 1367 & 61.6 & 62.0 & 99.0 & 75.8 & 126.0 \\
\hline Yield/pant (kg) & $0.39-2.26$ & 0.95 & 0.43 & 0.44 & 69.0 & 70.0 & 96.5 & 1.32 & 141.0 \\
\hline Fruit length (cm) & 3.7-18.5 & 10.6 & 18.4 & 20.1 & 40.46 & 44.8 & 91.5 & 8.7 & 82.2 \\
\hline Fruit breadth $(\mathrm{cm})$ & $2.6-7.7$ & 4.2 & 1.54 & 1.68 & 29.5 & 30.8 & 91.6 & 2.53 & 91.0 \\
\hline \% Borer infestation & $4.2-20.6$ & 9.2 & 11.8 & 34.5 & 37.86 & 63.8 & 34.2 & 5.5 & 59.0 \\
\hline
\end{tabular}


Table 3. Correlation coefficient between yield and different yield attributes.

\begin{tabular}{|c|c|c|c|c|c|c|c|c|c|}
\hline Traits & $\begin{array}{l}\text { Days to } \\
\text { first } \\
\text { flowering }\end{array}$ & $\begin{array}{l}\text { Plant } \\
\text { height } \\
(\mathrm{cm})\end{array}$ & $\begin{array}{l}\text { No. of } \\
\text { fruits/plant }\end{array}$ & $\begin{array}{l}\text { Individual } \\
\text { fruit wt. (g) }\end{array}$ & $\begin{array}{c}\text { Fruit } \\
\text { length } \\
(\mathrm{cm})\end{array}$ & $\begin{array}{l}\text { Fruit } \\
\text { breadth } \\
(\mathrm{cm})\end{array}$ & $\begin{array}{l}\text { \% Borer } \\
\text { infestation }\end{array}$ & $\begin{array}{c}\text { Yield/ } \\
\text { plant (kg) }\end{array}$ & $\begin{array}{l}\text { Yield } \\
(\mathrm{t} / \mathrm{ha})\end{array}$ \\
\hline \multicolumn{2}{|l|}{ Days to first flowering } & -0.06 & -0.081 & -0.073 & 0.096 & -0.038 & 0.03 & -0.2 & -0.18 \\
\hline \multicolumn{2}{|l|}{ Plant height } & & 0.18 & -0.014 & -0.015 & 0.22 & -0.37 & 0.058 & 0.14 \\
\hline \multicolumn{2}{|l|}{ Number of fruits/pant } & & & -0.33 & -0.21 & -0.11 & -0.47 & $0.47 * *$ & $0.59 * *$ \\
\hline \multicolumn{2}{|c|}{ Individual fruit fruits weight (g) } & & & & 0.23 & 0.71 & 0.081 & 0.3 & 0.53 \\
\hline \multicolumn{2}{|l|}{ Yield/pant (kg) } & & & & & -0.37 & $0.49 * *$ & 0.15 & 0.15 \\
\hline \multicolumn{2}{|l|}{ Fruit length $(\mathrm{cm})$} & & & & & & -0.3 & 0.12 & -0.62 \\
\hline \multicolumn{2}{|l|}{ Fruit breadth (cm) } & & & & & & & -0.62 & -0.62 \\
\hline \multicolumn{2}{|l|}{ \% Borer infestation } & & & & & & & & $0.40^{* *}$ \\
\hline
\end{tabular}

**Significant at $1 \%$ level 
plant exhibited very high heritability with very high genetic advance as percent of mean. Fruit length and fruit breadth also showed high heritability with high genetic advance. In general, the characters, which exhibit high heritability with high genetic advance, are significantly controlled by additive genes (Panse, 1967) and can be improved through mass selection, progeny selection or any other modified selection procedures. The high heritability and high genetic advance for number of fruits per plant, individual fruit weight, and yield per plant indicated that selection could be made for improvement.

The values for correlation coefficient are presented in Table 3. Number of fruits per plant and individual fruit weight were highly and positively correlated $\left(\mathrm{r}=0.59^{* *}\right.$ and $0.53^{* *}$, respectively) with fruit yield (t/ha). Therefore, those parameters should be kept in mind for better planning of any improvement programme in eggplant.

\section{Refercnces}

Ahmed, M. S., M. A. Rashid, M. A. A. Mannan and A. K. M. A Hossain. 1988. A study on the performance of thirty six genotypes of brinjal. Bangladsh J. Agril. Res, 13 (11): $41-46$

Burton, G. W. and E. H. De Vane. 1953. Estimating heritability in tall fescue (Festuca arundinacea) from replicated colonial material. Agron. J. 45: 478-481.

Basar, A. Z. R. 1999. Genetic divergence in brinjal. An MS Thesis, Dept of Genetics and Plant Breeding, BSMRAU, Salna, Gazipur. 46p

Chowdhury, M. S. I. 2005. Study on genetic diversity and characterization of some cultivars of eggplant. An M. S. Thesis. Dept of Horticulture, BSMRAU, Salna, Gazipur.7 $1 \mathrm{p}$

Misra, G. M. 1961. Investigations on hybrid vigour in brinjal (Solanum. melongena L). Indian J. Hort. 18: 305-3 16.

Panse, V. G. and P. V. Sukhatme. 1967. Statistical methods for agricultural workers. Second Edition. Indian Council of Agricultural Research, New Delhi. pp.381.

Panse, V.G.1967. Genetics of quantitative characters in relation to plant breeding. Indian J. Genet. 17: 3 18-328.

Rashid, M. M. 1995. Sabji Biggan (In Bengali), Bangla Academy, Dhaka, pp. 455.

Robinson, H. F., R. E. Comstock and B. H. Harvey. 1959. Estimation of heritability and the degree of dominance in corn. Agron. J. 42: 353-359.

Thakur, M. R., K. Singh and J. Singh. 1968. Hybrid vigour studies in Brinjal (Solanum Menolgena L). J. Res. Ludhiana 5: 490-495.

Ushakumari, R., M. Subramanian and S. Subramanian. 1991. Studies on coefficient of variation and heritable components of some quantitative characters in brinjal. Indian J. of Horti. 48(1): 75-78. 